\title{
Reallocation of Capital and Labor within Firms
}

\author{
Holger Mueller ${ }^{a}$
}

JEL-Classification: D23, G31, G32

Keywords: boundaries of the firm, internal capital markets, capital and labor reallocation

\section{SUMMARY}

Understanding how internal capital and labor markets function sheds light on one of the most fundamental questions in economics: what determines the boundaries of the firm? This essay reviews the theoretical and empirical literature on internal capital markets and firm boundaries, focusing in particular on the close link between the two subjects. Emphasis is placed on the question of how firms reallocate capital and labor internally across individual firm units in response to plausibly exogenous shocks. The essay concludes with directions for future research.

a Nomura Professor of Finance at New York University Leonard N. Stern School of Business, 44 West 4th Street, New York, NY 10012, USA. Email: hmueller@stern.nyu.edu. 


\section{Introduction}

Why study capital and labor reallocation within firms? As I argue in this essay, understanding how internal capital and labor markets function is closely related to one of the most fundamental questions in economics, namely, what determines the boundaries of the firm. This essay proceeds in reverse order. I begin with the literature on firm boundaries, arguing that internal capital allocation plays a central role for the boundaries of the firm. I subsequently discuss some empirical work on internal capital markets, focusing in particular on the reallocation of capital and labor within firms. I conclude with some directions for future research.

\section{Internal Capital Markets and the Boundaries of the Firm}

In his 1937 article, Ronald Coase raised one of the most fundamental questions in economics: why are there firms? In Coases' own words: "If production could be carried out without any organisation at all, well might we ask, why is there any organisation?" This question, as we understand it today, not only asks why firms exist but also what determines their optimal size and scope. Specifically, why are certain transactions carried out within firms while others are carried out through arms' lengths transactions in the market? If organizing production through firms has benefits, why is not all production carried out within a single firm? In other words, what determines the boundaries of the firm?

Coase's answer is that some transactions are carried out within firms because it is difficult to write fully contingent contracts that specify what should happen in all possible future situations. This notion of what is nowadays referred to as "contractual incompleteness" provides a role for the existence of firms if they are able to fill the void left by incomplete contracts. Specifically, Coase argues that firms can substitute for missing contractual contingencies with "authority." Simply put, when contracts are silent, the firm's owner can dictate its employees what to do. To define the boundaries of the firm, Coase invokes diminishing marginal returns from management as well as resources wasted within firms.

What Coase is somewhat less clear about is what exactly are the transaction costs arising from contractual incompleteness. Thirty years later, Williamson (1975) and Klein, Crawford, and Alchian (1978) provide an answer to this question by introducing an inefficiency that is commonly known as the "holdup problem." Specifically, when there are relationship-specific investments, contractual incompleteness gives rise to ex-post opportunism in the sense that the 
party making the investment is not properly rewarded once the investment is sunk. This fear of ex-post opportunism may discourage parties from making efficient investments ex ante.

While the contributions by Williamson (1975) and Klein, Crawford, and Alchian (1978) stress the importance of the hold-up problem, they are less clear about what precisely are the benefits from integration. That is, how exactly is the hold-up problem mitigated within firms? Ten years later, Grossman and HarT (1986) and Hart and Moore (1990) point to the crucial role of ex-post bargaining when the division of surplus cannot be fully specified in ex-ante incomplete contracts. In particular, they argue that asset ownership confers bargaining power in negotiations. This is because the asset's owner has residual control rights allowing him to exclude others from its use. Accordingly, agents can guard themselves against ex-post opportunism by owning the assets they invest in. If several agents make asset-specific investments, then the agent whose investment is more important should own the asset.

Although the Grossman-Hart-Moore "property rights approach" is widely hailed as a breakthrough in the theory of the firm, critics have questioned its usefulness in understanding real-world firms. The reason is that in reality firms, not managers, own the assets used in the production process. HOLMSTRöm (1999) notes: "[T]his model, despite its express objective to explain the boundaries of the firm, fails to do so, at least if the model is interpreted literally. The model offers a theory of individual ownership of assets, that is, how control over assets should be distributed among individuals, but it does not explain why firms own assets." Likewise, Bolton and SCharfstein (1998) argue: "[I]t is not so clear how one would use this model to understand, for example, the acquisition by a large multidivisional firm of one of its suppliers. Managers don't own their companies' assets, though they may control their use. How then might we think about the boundaries of the firm when managers control assets but don't own them?"

What features of real-world firms should a plausible model of firm boundaries be consistent with? For one, control over the firm's assets should reside with corporate headquarters (HQ), even though i) HQ itself is not the owner of the assets - it is merely given authority by the firm's owners (i. e., shareholders), and ii) HQ itself makes no relationship-specific investments. As Bolton and SCHARFSTEIN (1998) point out, "The Grossman-Hart-Moore framework [...] predicts that control should be allocated to parties whose relationship-specific investments are most important to the relationship. Yet headquarters is given control, even though it does not really make such investments."

Hence, a realistic model of firm boundaries should feature centralized decision making under HQ. While not the owner, HQ has effective control over the 
firm, including its assets. In particular, HQ can control divisions' investment by giving more funds to some divisions (or projects) and less to others. Notice the difference between HQ and an external lender, such as a bank. Lacking control rights, a bank cannot prevent a firm from going to another bank, nor can it redistribute funds from one borrower to another. STEIN (2003) summarizes this "capital-allocation-centric" view on the question of firm boundaries as follows: "Loosely speaking, a collection of assets should optimally reside under the roof of a single firm to the extent that the firm's internal capital market can do a more efficient job of allocating capital to these assets than would the external capital market, if the assets were located in distinct firms."

Why should HQ do a better (or worse) job of allocating capital to projects compared to the external capital market? First and foremost, HQ has authority. That is, unlike, e. g., a bank, HQ can simply dictate the efficient (re-)allocation of capital and labor within a firm. Second, because HQ has authority, it has strong monitoring incentives. That is, authority and monitoring are complements (Alchian, 1969; Williamson, 1975; Gertner, Stein, and ScharfSTEIN, 1994; STEIN, 1997). Third, because HQ can, by virtue of its authority, reallocate funds from "losers" to "winners," centralized firms under HQ control may be able to raise more external funds than comparable stand-alone firms (Lewellen, 1971; Stein, 1997; Inderst and Mueller, 2003). On the other hand, giving HQ authority may discourage managerial incentives (AGHION and Tirole, 1997; Brusco and Panunzi, 2005) or lead to intra-firm lobbying and rent-seeking, resulting in an inefficient capital allocation (MEYER, MiLgrom, and Roberts, 1992; Scharfstein and Stein, 2000; Rajan, Servaes, and Zingales, 2000).

\section{Internal Capital Markets: Empirical Evidence}

Direct empirical evidence on internal capital markets is relatively scant. The reason is that readily available data do not permit a look inside the firm, and if they do, the data are often subject to (self-) reporting and other biases. A commonly used data source, especially among earlier studies, are the business-segment data provided by Compustat. Based on these data, several studies in the mid- to late 1990s document that conglomerate firms trade at a discount relative to a portfolio of comparable stand-alone firms (LANG and STUlZ, 1994; BERGER and Ofek, 1995; Servaes, 199; Lins and Servaes, 1999). This empirical result, commonly referred to as "conglomerate discount" or "diversification discount," can potentially speak to the (dys-)functioning of internal capital markets. Indeed, 
as some researchers argue, a possible explanation for the conglomerate discount is inferior capital allocation due to increased agency problems within conglomerate firms.

While the conglomerate discount literature has made quite a splash in the corporate finance profession, critics have argued that its methodology and the data used to obtain the discount are flawed. In a nutshell, the discount is the difference between a conglomerate firm's Tobin's $q$ and the weighted average $q$ associated with a portfolio of "comparable" stand-alone firms. The conglomerate firm's $q$ is the market value of the firm divided by either the replacement value of its assets or the book value of its debt and equity ("market-to-book"). To obtain the $q$ s of comparable stand-alone firms, researchers typically use the average $q$ of single-segment firms operating in same industry as the conglomerate segment.

As for data quality, critics have pointed out that firms self-report segment data, and changes in number of segments may therefore reflect changes in reporting practices rather than changes in the degree of diversification. In particular, Hyland (1997) argues that this issue arises in $25 \%$ of all cases. Likewise, VILLALONGA (2004) argues that in $80 \%$ of all cases, the segment's SIC code assigned by Compustat is not the SIC code of the segment's largest industry. Indeed, using Census (BITS) data, which provide correct SIC codes, Villalonga (2004) finds that the conglomerate discount turns into a conglomerate premium.

On the methodology side, the main issue is the endogeneity of the decision to join or form a conglomerate. Effectively, the question is whether a portfolio of "comparable" stand-alone firms constitutes a valid counterfactual. After all, there may be good reasons why some firms remain stand-alone firms. Simply put, estimates of the conglomerate discount may be biased due to unobserved heterogeneity. In this vein, Campa and Kedia (2002), Graham, Lemmon, and Wolf (2002), and Villalonga (2004) all conclude that "correcting" for the endogeneity makes the conglomerate discount disappear or turn into a premium. Arguably, "correcting" for the endogeneity is rather difficult in the absence of plausibly exogenous variation in the conglomeration decision.

Perhaps more useful - because more direct - evidence on the functioning of internal capital markets comes from the empirical literature studying investment within conglomerate firms. In this regard, Scharfstein (1998), SHIN and Stulz (1998), and Rajan, Servaes, and Zingales (2000) all find that conglomerate firms overinvest relative to comparable stand-alone firms in segments with low investment opportunities and underinvest in segments with good investment opportunities. Thus, conglomerates are plagued by inefficient cross-subsidization, often referred to as "corporate socialism." As in the conglomerate discount 
literature, however, the question is whether "comparable" stand-alone firms constitute a valid counterfactual. Indeed, Whited (2001) argues that conglomerate segments may not have the same investment opportunities as stand-alone firms. After correcting for potential measurement error bias, she finds no difference between the investment behavior of conglomerates and that of standalone firms. Perhaps more strikingly, Chevalier (2000) finds that conglomerate divisions exhibit the same ("inefficient") cross-subsidization pattern already before they merge, implying that the cross-subsidization pattern found in other studies cannot possibly be due to "socialistic" internal capital markets within conglomerates.

An alternative approach to studying internal capital markets is to examine how firms respond to "shocks" to one of their divisions (or projects). To the extent that these shocks are plausibly exogenous, this could provide interesting insights into how internal capital markets operate. If internal capital markets are efficient, we would expect that HQ reallocates budgets (and thus "capital" and "labor") within the firm so as to maximize overall firm value. STEIN (1997) succinctly summarizes the "efficient internal capital markets hypothesis" as follows: "Thus, for example, if a company owns two unrelated divisions A and B, and the appeal of investing in B suddenly increases, the argument would seem to imply that investment in A would decline - even if it is positive NPV at the margin as corporate headquarters channels relatively more of its scarce resources toward B." Along similar lines, SHIN and STULZ (1998) define an internal capital market to be efficient if "its allocation of funds to a segment falls when other segments have better investment opportunities."

There are relatively few studies that look into how internal capital markets respond to exogenous shocks. One of the earliest studies is Lamont (1997). He finds that in 1986, when oil prices declined by $50 \%$, integrated oil companies cut investment across the board, including investment in non-oil segments. While Lamont's paper suggests an interdependence across otherwise unrelated divisions, the underlying experiment differs from STEIN's (1997) thought experiment outlined above. In Stein's experiment, some divisions experience a decrease in investment while others experience an increase. By contrast, in Lamont's study, there is no shock to investment opportunities but rather a liquidity shock to one (namely, the oil) division which is then "shared" with other divisions. Hence, investment declines across the board. Another interesting industry study is Khanna and TiCE (2001), who examine Wal-Mart's entry into local markets between 1975 and 1996. They find that conditional on staying in the market, investment by discount divisions of diversified firms becomes more sensitive to division profitability than does investment by stand-alone discount retailers. Moreover, diversified 
firms transfer funds away from failing discount divisions. Both LAmont (1997) and Khanna and Tice (2001) feature reasonably well identified shocks. However, both studies are limited to small samples (26 integrated oil companies and 25 discount divisions of diversified retailers, respectively).

At the other end of the spectrum are studies using large samples but without exogenous shocks. Using Compustat segment data, SHIN and Stulz (1998) regress investment by a segment on the industry $q s$ of the firm's other segments. They overwhelmingly reject the view that the $q$ s of the other segments affect the segment's investment, concluding that "unless one believes that firms face no costs of external finance, this evidence suggests that the internal capital market does not allocate resources efficiently." Maksimovic and Phillips (2002) do not use Compustat segment data but rather construct segment-level observations by aggregating Census plant-level data at the firm-industry level. The authors show that a segment's sales growth is negatively (positively) correlated with the other segments' productivity if the segment's sales growth at the industry level is lower (higher) than that of the firm's median segment. In both studies, identification comes from cross-sectional variation in segments' industry $q$ s and sales growth, respectively.

Overall, the existing evidence on internal capital markets seems inconclusive. While some studies suggest that internal capital markets do not operate efficiently, others suggest the opposite. With few exceptions, existing studies rely on Compustat segment data, meaning their results must be interpreted with some caution. Studies that do not use Compustat segment data provide suggestive but not causal evidence of spillovers from one division to another. Finally, studies based on specific shocks are mostly industry studies using small samples.

\section{Capital and Labor Reallocation within Firms}

In Giroud and Mueller (2015a), we try to address many of the shortcomings listed in the previous paragraph. For one, we do not use Compustat segment data but rather confidential plant-level data provided by the U.S. Census Bureau's Census of Manufactures (CMF) and Annual Survey of Manufactures (ASM), respectively. Second, we use a large sample: almost 300000 plant-year observations. Third, we study plausibly exogenous shocks to plant-level investment opportunities allowing a relatively tight identification, which includes plant fixed effects (to control for time-invariant plant characteristics) and MSA x year fixed effects (to control for time-varying shocks in the plant's vicinity.) 
The objective of our study is to shed light on the efficient internal capital markets hypothesis. As discussed previously, this hypothesis posits that HQ can create value by actively reallocating scarce resources within the firm: ${ }^{1}$

Thus, for example, if a company owns two unrelated divisions $A$ and $B$, and the appeal of investing in B suddenly increases, the argument would seem to imply that investment in A would decline - even if it is positive NPV at the margin - as corporate headquarters channels relatively more of its scarce resources toward B (STEIN, 1997, italics added).

To obtain exogenous variation in the "sudden increase in the appeal of investing in a plant," we use the introduction of new airline routes that reduce the travel time between HQ and plants. Giroud (2013) uses this source of variation to study whether proximity to HQ affects plant-level investment. The idea is that a reduction in travel time makes it easier for HQ to monitor a plant, give advice, share knowledge, etc., raising the plant's marginal productivity and thus making investment in the (treated) plant more appealing. Consistent with this idea, Giroud finds that a reduction in travel time leads to an increase in plantlevel productivity and investment.

The main benefit of using travel time instead of geographical proximity is that plant location is endogenous. By contrast, holding plant location fixed, variation in travel time is plausibly exogenous with respect to plant-level outcomes. A second benefit is that travel time constitutes a more direct proxy for the ease of monitoring. For example, a plant may be located far away from HQ, yet monitoring may be easy, because there exists a short direct flight. Conversely, a plant may be located in the same state as HQ, yet monitoring may be costly because it involves a long trip by car.

In our study, we use the "sudden increase in the appeal of investing in a plant" as a starting point and ask whether it leads to a reallocation of resources within the firm. Theory predicts that HQ should withdraw resources from existing plants only if the firm is financially constrained. (Note the emphasis on scarce resources in Stein's quote.) Accordingly, we separately examine financially constrained and unconstrained firms. We also examine whether, to provide the treated plant with resources, HQ selectively "taxes" some plants more than others. We finally examine whether the reallocation is beneficial for the firm as a whole, as argued by the efficient internal capital markets hypothesis.

The main identification challenge comes from local shocks at the plant level. For instance, suppose a plant is located in a region that experiences an economic

1 In other words, HQ reallocates budgets or funds, which then translate into an allocation of resources (capital and labor) among the firm's projects and divisions. 
boom. As a result, HQ may find it more attractive to invest in the plant. By the same token, airlines may find it more attractive to introduce new routes to the plant's location. Thus, local shocks may be driving both plant-level investment and the introduction of new airline routes. Fortunately, we can control for such local shocks by including a full set of MSA x year fixed effects. The fixed effects are identified because not all local plants have their HQ in the same region.

Controlling for local shocks also matters with regard to the firm's other (that is, non-treated) plants. In particular, it implies that a decline in resources at these plants is not simply due to an adverse local shock that might have affected the plants anyway, i. e., if they had been stand-alone entities. Thus, controlling for local shocks allows us to address a key premise of the theory of the firm, namely, that combining different projects under one roof creates an interdependence among otherwise unrelated projects.

Our plant-level results support the hypothesis that HQ reallocates scarce resources across plants. For financially constrained firms, we find that investment and employment both increase at the treated plant, while they both decline at other plants within the same firm. Indeed, the increase at the treated plant is of similar magnitude as the decline at the other plants: investment (employment) at the treated plant increases by $\$ 186000$ (five employees), while it declines by $\$ 179000$ (six employees) at all other plants combined. In contrast, we find no evidence of investment or employment spillovers among plants of financially unconstrained firms.

If HQ actively reallocates scarce resources across plants, then the increase in investment and employment at the treated plant and the decline at the other plants should occur around the same time. This is indeed the case: the increase at the treated plant and the decline at the other plants both begin about one year after the treatment. Moreover, we find no pre-existing differential trends, strengthening a key identifying assumption underlying our difference-in-differences analysis.

While the firm's other plants experience a decline in resources, the average spillover effect is relatively weak. There are several reasons for this. First, the amount of resources needed to "feed" the treated plant - and thus the amount HQ must take away from other plants - is relatively modest. Second, this amount is divided among many other plants, implying that the average amount that is taken away from any individual plant is small. Indeed, when we focus on firms that have relatively few other plants, the spillover effect becomes much stronger. Third, the average spillover effect is likely to be noisy. Presumably, HQ does not "tax" all of the firm's other plants equally: while some plants may experience a large drop in resources, others may experience none. To examine this hypothesis, 
we look at various plant characteristics. We find that HQ is more likely to take resources away from plants that are relatively less productive, not part of the firm's core industries, and located far away from HQ. When we focus on these plants, we again find that the spillover effect becomes much stronger.

Our main measures of financing constraints are the KZ index (KAPLAN and Zingales, 1997) and the WW index (Whited and Wu, 2006). In robustness checks, we additionally use the SA index (Hadlock and Pierce, 2010), debtto-cash flow ratio, investment in excess of cash flow, and whether firms have a credit rating. These measures have been designed to capture financing constraints, so we naturally interpret our results in this light. Still, it is conceivable that the resource reallocation occurs for reasons unrelated to financing constraints. To a certain extent, this issue can be addressed by looking at financially unconstrained firms. For instance, suppose the treated plant produces the same type of output as the firm's other plants, while the firm's total output volume is given by its market share, which is fixed in the short run. Then, if the firm produces more at the treated plant, it must produce less at the other plants. While this creates an interdependence among plants, the mechanism causing it is unrelated to financing constraints. However, in this case, we should also observe a decline in resources at other plants of financially unconstrained firms. (Essentially, such plants constitute a "placebo group".) We do not observe any such decline, however, suggesting that the likely reason why HQ withdraws resources from existing plants is precisely because the firm is financially constrained.

Looking at financially unconstrained firms does not help if our measures of financing constraints proxy for other variables that are (economically) unrelated to financing constraints but nevertheless affect the resource reallocation within the firm. While we cannot rule out this possibility completely, we can address specific alternative stories. For instance, our measures of financing constraints are uncorrelated with productivity measures. Thus, our results are unlikely to be driven by differences in productivity. Another possible candidate is firm size. While some of our measures of financing constraints are correlated with firm size, others are not, including the $\mathrm{KZ}$ index, debt-to-cash flow ratio, and investment in excess of cash flow. Thus, our results are also unlikely to be driven by differences in firm size.

In the final part of our study, we consider the aggregate (or net) effect at the firm level. For financially constrained firms, we find that the aggregate effect on investment and employment is essentially zero, consistent with our plant-level results showing that the increase at the treated plant is of similar magnitude as the decline at the other plants. By contrast, the aggregate effect on investment and employment at financially unconstrained firms is strictly positive. Given 
that these firms exhibit no (negative) spillovers among their plants, this is not entirely surprising.

A key premise of the efficient internal capital markets hypothesis is that the resource reallocation is overall beneficial: while resources may be taken away from projects that have a positive NPV at the margin, they are channeled toward other projects whose investment prospects are even better. To investigate this issue, we consider the aggregate effect on productivity at the firm level. Doing so also helps us distinguish the efficient internal capital markets hypothesis from alternative stories. For example, the resource reallocation may be the outcome of lobbying by managers of the treated plant, who suddenly find it easier to lobby for a larger budget given that their travel time to HQ is reduced. While such lobbying efforts can explain why the treated plant gains at the expense of other plants - provided the firm is financially constrained - they are unlikely to yield an increase in overall firm-wide productivity. However, regardless of which productivity measure we use, we find that overall firm-wide productivity increases.

We finally consider other sources of funding. Our plant-level results suggest that financially constrained firms fund the expansion at the treated plant entirely by reallocating internal resources. Therefore, when looking at other sources of funding, we would expect to see no changes. By contrast, financially unconstrained firms do not reallocate internal resources. Accordingly, we would expect to see changes in other sources of funding at these firms. Indeed, we find that financially unconstrained firms fund the expansion at the treated plant by issuing debt and drawing down cash reserves, while financially constrained firms exhibit no significant changes in their cash, short-term debt, long-term debt, or equity positions.

\section{Directions for Future Research}

Our study (Giroud and Mueller, 2015a) shows that following a positive shock to investment opportunities at one plant, investment and employment increase at the treated plant while they both decline at other plants within the same firm. An interesting question our study cannot address is to what extent workers are physically transferred across plants. That is, HQ reallocates budgets or funds, which then translate into allocations of capital and labor. Hence, our results are consistent with either workers being physically moved across plants or some plants hiring new workers and others laying off workers. Presumably, workers are physically transferred only if the plants are close to one another, albeit that is ultimately an empirical question. To shed light on this issue, one would need to have access 
to employer-employee matched data, such as those provided by the U.S. Census Bureau's Longitudinal Employer-Household Dynamics (LEHD) database.

Another question that remains unanswered by our study is whether internal capital markets create value relative to external capital markets. As I argued previously, this question lies at the heart of the broader issue of what determines the boundaries of the firm. While our study shows that internal capital markets operate fairly well - capital and labor are shifted toward plants whose investment opportunities have improved - it cannot say whether they operate "more efficiently" than external capital markets would have. To tackle this question, however, one needs to overcome the ubiquitous endogeneity problem that has plagued the internal capital markets literature ever since the first studies on the diversification discount have come out. That is, one would need to find plausibly exogenous variation in the decision to join a multi-unit firm, which is arguably challenging.

Finally, an interesting yet virgin research territory is the role of internal capital markets for the macro economy. If shocks are propagated from one establishment (region) to another, does this dampen or amplify macroeconomic volatility? Consider an adverse local shock, such as the drop in local consumer demand during the Great Recession studied by, e. g., Mian and Sufi (2014) and Giroud and Mueller (2015b). For one, affected establishments or regions may suffer less, as their local shock is "shared" with other establishments or regions. On the other hand, previously unaffected establishments or regions may now be affected. Overall, the aggregate implications of such capital and labor reallocations are entirely unclear.

\section{References}

Aghion, P., and J. Tirole (1997), "Formal and Real Authority in Organizations", Journal of Political Economy, 105, pp. 1-29.

Alchian, A. (1969), "Corporate Management and Property Rights", in Economic Policy and the Regulation of Corporate Securities, H. Manne, ed., Washington, D. C.

Berger, P., and E. Ofek (1995), "Diversification's Effect on Firm Value”, Journal of Financial Economics, 37, pp. 39-65.

Bolton, P., and D. Scharfstein (1998), "Corporate Finance, the Theory of the Firm, and Organizations", Journal of Economic Perspectives, 12, pp. 95-114. 
Brusco, S., and F. Panunzi (2005), "Reallocation of Corporate Resources and Managerial Incentives in Internal Capital Markets, European Economic Review, 49, pp. 659-681.

Campa, J., and S. Kedia (2002), "Explaining the Diversification Discount", Journal of Finance, 57, pp. 1731-1762.

Chevalier, J. (2000), "What Do We Know about Cross-Subsidization? Evidence from the Investment Policies of Merging Firms", mimeo, University of Chicago.

Coase, R. (1937), “The Nature of the Firm”, Economica, 4, pp.386-405.

Gertner, R., D. Scharfstein, and J. Stein (1994), "Internal versus External Capital Markets”, Quarterly Journal of Economics, 109, pp. 1211-1230.

Giroud, X. (2013), "Proximity and Investment: Evidence from Plant-Level Data”, Quarterly Journal of Economics, 128, pp. 861-915.

Giroud, X., and H. Mueller (2015a), "Capital and Labor Reallocation within Firms", Journal of Finance, 70, pp. 1767-1804.

Giroud, X., and H. Mueller (2015b), "Firm Leverage, Consumer Demand, and Unemployment during the Great Recession", mimeo, New York University.

Graham, J., M. Lemmon, and J. Wolf (2002), "Does Corporate Diversification Destroy Value?”, Journal of Finance, 57, pp. 695-720.

Grossman, S., and O. Hart (1986), "The Costs and Benefits of Ownership: A Theory of Vertical and Lateral Integration”, Journal of Political Economy, 94, pp. 691-719.

Hadlock, C., and J. Pierce (2010), "New Evidence on Measuring Financial Constraints: Moving Beyond the KZ Index", Review of Financial Studies, 23, pp. 1909-1940.

Hart, O., and J. Moore (1990), "Property Rights and the Nature of the Firm", Journal of Political Economy, 98, pp. 1119-1158.

Holmström, B. (1999), "The Firm as a Subeconomy”, Journal of Law, Economics and Organization, 15, pp. 74-102.

Hyland (1997), "Why Firms Diversify: An Empirical Examination", unpublished doctoral dissertation, Ohio State University.

Inderst, R., and H. Mueller (2003), "Internal versus External Financing: An Optimal Contracting Approach", Journal of Finance, 58, pp. 1033-1062.

Kaplan, S., and L. Zingales (1997), "Do Financing Constraints Explain Why Investment Is Correlated with Cash Flow?", Quarterly Journal of Economics, 112, pp. 169-215.

Khanna, N., and S. Tice (2001), "The Bright Side of Internal Capital Markets", Journal of Finance, 56, pp. 1489-1528. 
Klein, B., R. Craw ford, and A. Alchian (1978), "Vertical Integration, Appropriable Rents, and the Competitive Contracting Process", Journal of Law and Economics, 21, pp. 297-326.

Lamont, O. (1997), "Cash Flow and Investment: Evidence from Internal Capital Markets", Journal of Finance, 52, pp. 83-109.

Lang, L., and R. STulz (1994), “Tobin's q, Corporate Diversification, and Firm Performance”, Journal of Political Economy, 102, pp. 1248-1280.

Lewellen, W. (1971), "A Pure Financial Rationale for the Conglomerate Merger", Journal of Finance, 26, pp. 521-537.

Lins, K., and H. Servaes (1999), "International Evidence on the Value of Corporate Diversification", Journal of Finance, 54, pp. 2215-2239.

Maksimovic, V., and G. Phillips (2002), "Do Conglomerate Firms Allocate Resources Inefficiently across Industries? Theory and Evidence", Journal of Finance, 57, pp. 721-767.

Meyer, M., P. Milgrom, and J. Roberts (1992), "Organizational Prospects, Influence Costs, and Ownership Changes", Journal of Economics and Management Strategy, 1, pp. 9-35.

Mian, A., and A. Sufi (2014), "What Explains the 2007-2009 Drop in Employment?", Econometrica, 82, pp. 2197-2223.

Rajan, R., H. Servaes and L. Zingales (2000), "The Cost of Diversity: The Diversification Discount and Inefficient Investment", Journal of Finance, 55, pp. 35-80.

Scharfstein, D. (1998), "The Dark Side of Internal Capital Markets II: Evidence from Diversified Conglomerates”, NBER Working Paper 6352.

Scharfstein, D., and J. Stein (2000), "The Dark Side of Internal Capital Markets: Divisional Rent-Seeking and Inefficient Investment", Journal of Finance, 55, pp. 2537-2564.

Servaes, H. (1996), "The Value of Diversification during the Conglomerate Merger Wave”, Journal of Finance, 51, pp. 1201-1225.

Shin, H.-H., and R. Stulz (1998), "Are Internal Capital Markets Efficient?", Quarterly Journal of Economics, 113, pp. 531-552.

Stein, J. (1997), "Internal Capital Markets and the Competition for Corporate Resources”, Journal of Finance, 52, pp. 111-133.

Stein, J. (2003), "Agency, Information and Corporate Investment", in Handbook of the Economics of Finance, G. Constantinides, M. Harris, and R. Stulz, eds., Amsterdam.

Villalonga, B. (2004), "Does Diversification Cause the 'Diversification Discount'?", Financial Management, 33, pp.5-27. 
Whited, T. (2001), "Is it Inefficient Investment that Causes the Diversification Discount?", Journal of Finance, 56, pp. 1667-1691.

Whited, T., and G. Wu (2006), "Financial Constraints Risk", Review of Financial Studies, 19, pp. 531-559.

Williamson, O. (1975), Market and Hierarchies: Analysis and Antitrust Implications, New York. 